\title{
Biomass, production and horizontal patchiness of sea ice algae in a high-Arctic fjord (Young Sound, NE Greenland)
}

\author{
Søren Rysgaard ${ }^{1, *}$, Michael Kühl ${ }^{2}$, Ronnie Nøhr Glud ${ }^{2}$, Jens Würgler Hansen ${ }^{1}$ \\ ${ }^{1}$ Department of Lake and Estuarine Ecology, National Environmental Research Institute, Vejlsøvej 25, 8600 Silkeborg, \\ Denmark \\ ${ }^{2}$ Marine Biological Laboratory, University of Copenhagen, Strandpromenaden 5, 3000 Helsingør, Denmark
}

\begin{abstract}
A study of the variation in sea ice algal distribution and production was performed during June and early July 1999 in Young Sound, northeastern Greenland. Measurements were performed in situ by divers using an underwater pulse-amplitude-modulated (PAM) fluorometer, oxygen microelectrodes and ${ }^{14} \mathrm{C}$ incubations. In early June, Young Sound was covered by $\sim 1.6 \mathrm{~m}$ of sea ice and $\sim 30 \mathrm{~cm}$ of dry snow, which reflected $\sim 75 \%$ of the incident light. These conditions resulted in low irradiance below the sea ice $\left(<2 \mu \mathrm{mol}\right.$ photons $\left.\mathrm{m}^{-2} \mathrm{~s}^{-1}\right)$, low values of chlorophyll a $\left(<1 \mu \mathrm{g} \mathrm{l}^{-1}\right.$ sea ice $)$ and low primary productivity $\left(<0.05 \mu \mathrm{g} \mathrm{Cl}^{-1} \mathrm{~h}^{-1}\right)$ in the bottom ice $(0$ to $4 \mathrm{~cm})$. The snow cover gradually disappeared during June, resulting in increased light penetration of up to $20 \mu \mathrm{mol}$ photons $\mathrm{m}^{-2}$ $\mathrm{s}^{-1}$, chl a concentrations of up to $15 \mu \mathrm{g} \mathrm{l}^{-1}\left(0.6 \mathrm{mgC} \mathrm{m}^{-2}\right)$, and primary production rates of up to $0.2 \mu \mathrm{g} \mathrm{Cl}^{-1} \mathrm{~h}^{-1}\left(0.2 \mathrm{mgC} \mathrm{m}^{-2} \mathrm{~d}^{-1}\right)$ in the bottom ice. Light saturation curves of photosynthesis were obtained in situ on 3 occasions and showed adaptation of the sea ice algae to low irradiance; $E_{\mathrm{k}}$ values ranged from 12 to $35 \mu \mathrm{mol}$ photons $\mathrm{m}^{-2} \mathrm{~s}^{-1}$. Photosynthesis of sea ice algae resulted in supersaturated oxygen conditions (150 to $200 \%$ ) at the sea ice-water interface as compared to ambient seawater. In situ investigations of irradiance, algal biomass and photosynthetic activity on different metric scales showed a heterogeneous distribution of sea ice algae. Statistical treatment of the data obtained revealed that algal activity followed the light regime below the sea ice (radii of patches were 50 to $100 \mathrm{~m}$ ), whereas algal biomass patches were smaller (radii of patches were 5 to $10 \mathrm{~m}$ ). Sea ice algal production in Young Sound was 2 to $3 \mathrm{mg} \mathrm{C} \mathrm{m}^{-2}$ during June and July 1999. Compared to other coastal fast-ice areas this rate is low. We suggest that the low biomass and productivity in Young Sound was caused by a combination of poor light conditions due to snow cover and freshwater drainage from melt ponds and river discharge removing and/or inhibiting the algae at the sea icewater interface through physical disturbance and exposure to freshwater. The primary production of sea ice algae in Young Sound was $<1 \%$ of the annual pelagic primary production.
\end{abstract}

KEY WORDS: Sea ice algae $\cdot$ In situ measurements $\cdot$ PAM $\cdot$ Oxygen microprofiles $\cdot{ }^{14} \mathrm{C} \cdot \mathrm{P}-\mathrm{E}$ curves

\section{INTRODUCTION}

The complex structure of sea ice (Weissenberger et al. 1992) makes it difficult to apply in situ methods for measuring primary production, and such studies have mainly used different in situ tracer methods $\left({ }^{14} \mathrm{C}\right)$

\footnotetext{
*E-mail: sr@dmu.dk
}

(Smith \& Herman 1991, Mock \& Gradinger 1999). In situ methods imply minimum disturbance of the algal community, and measurements are performed under natural light, temperature, nutrient and chemical regimes. The major disadvantage of in situ tracer techniques is that production may be underestimated because of inadequate tracer diffusion or because the tracer is lost due to transport via brine channels away from the measuring area. Another disadvantage is that 

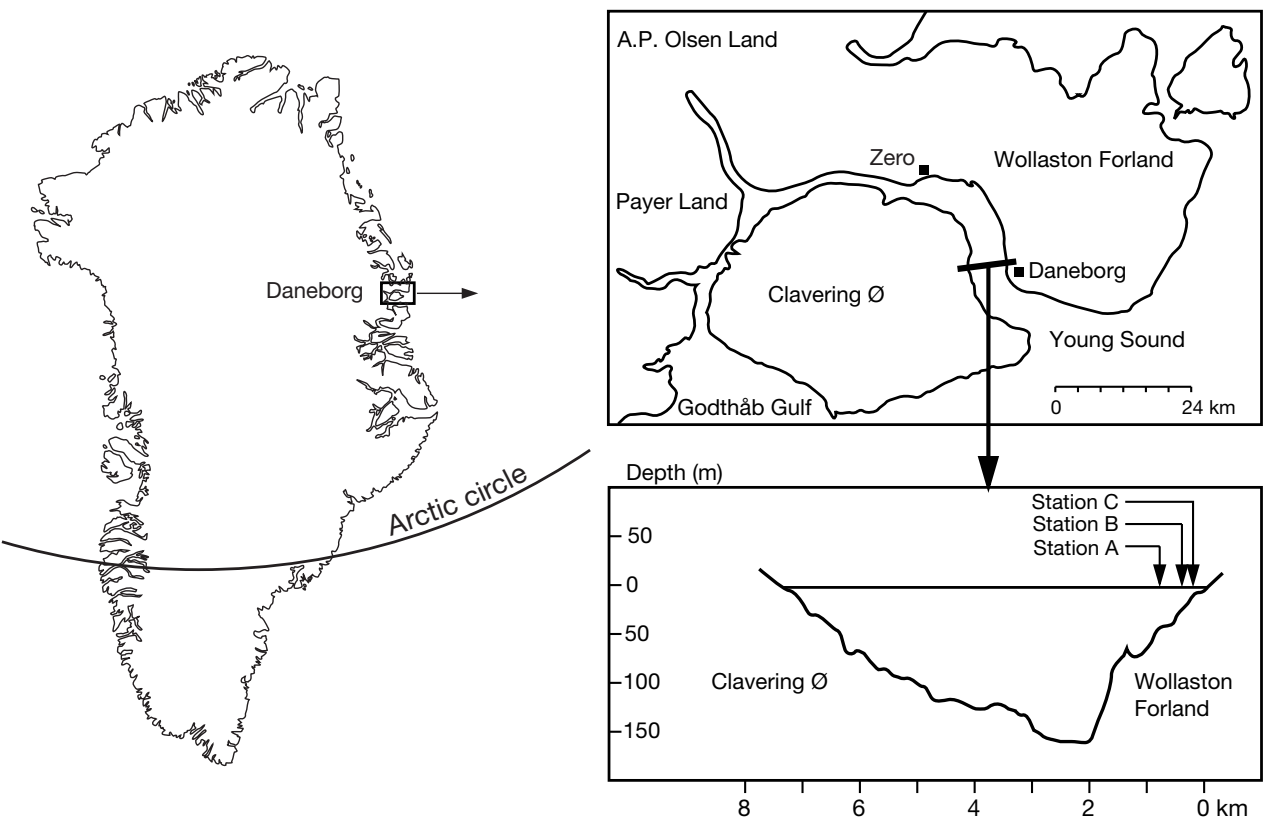

Fig. 1. Investigation area. The 3 study sites (Stns A to C) are indicated by arrows in situ tracer techniques are technically difficult and time-consuming, which sets an upper limit to replication and the number of measurements possible. Consequently, the spatial variability of sea ice algae and of their activity is an underexplored research area. Especially the microenvironment of sea ice biota is poorly characterized, but probably undergoes dramatic smallscale changes (Cota \& Smith 1991). Sea ice algae form narrow and structurally complex communities within sea ice, and proper analysis of such communities requires the use of miniaturized instrumentation (e.g. microprobes and microsamplers) capable of functioning in situ in both liquid and solid media (Cota \& Smith 1991). However, apart from ${ }^{14} \mathrm{C}$ tracer studies, little specialized sampling or experimental equipment has been developed for studying ice biota in situ. One exception is the investigation of net primary productivity of an Antarctic fast-ice algal community by use of oxygen microelectrodes (McMinn et al. 2000). The idea behind this technique is to measure the concentration gradient from the water column to the sea ice and to calculate the net oxygen flux. This approach relies on assumptions about the transport coefficient of oxygen, however, which is still poorly defined at the sea ice-water interface.

In the present study we estimate biomass, photoadaptional status and production in ice algae communities in situ using a waterproof pulse-amplitude-modulated (PAM) fluorometer combined with separate microelectrode measurements of oxygen (Kühl et al. 2001). With this equipment it is possible to perform numerous in situ measurements in time and space and thus investigate further the heterogeneity of sea ice algal biomass and production on different metric scales. The techniques were calibrated against traditional measurements of $\mathrm{chl} a$ and ${ }^{14} \mathrm{C}$.

The data add to the small database on sea ice algal production in NE Greenland (Gradinger et al. 1999), and present an essential basis for establishing a regional C-cycling model for this high-Arctic fjord system (Rysgaard et al. 1998,1999, Glud et al. 2000b, Levinsen et al. 2000, Sejr et al. 2000).

\section{MATERIALS AND METHODS}

Study site. The investigation was carried out during 7 June to 5 July 1999 in Young Sound, northeastern Greenland, at a location off Daneborg, $25 \mathrm{~km} \mathrm{SSE} \mathrm{of}$ the Zackenberg Ecological Research Station (Fig. 1). Initially, the sound was covered with $1.6 \mathrm{~m}$ of sea ice and $\sim 30 \mathrm{~cm}$ of snow. All measurements were performed in situ under the sea ice by SCUBA divers. Divers and in situ equipment entered through $1 \mathrm{~m}$ wide holes in the ice made with a motor-driven ice drill and by manual cutting. To avoid interference from locally enhanced irradiance, a wooden frame was inserted into the hole to prevent daylight from penetrating through the ice edge and further into the surrounding sea ice. Furthermore, all in situ measurements were performed $10 \mathrm{~m}$ from the hole. The seasonal work on sea ice was performed at Stn A ( $74^{\circ} 18^{\prime} 59^{\prime \prime} \mathrm{N}, 20^{\circ} 15^{\prime} 04^{\prime \prime} \mathrm{W}$ - water depth $36 \mathrm{~m}$ ). Heterogeneity measurements were performed at Stn A, Stn B (74 $14^{\circ} 59^{\prime \prime} \mathrm{N}, 20^{\circ} 14^{\prime} 39^{\prime \prime} \mathrm{W}$ - water depth $\left.17 \mathrm{~m}\right)$, and Stn C $\left(74^{\circ} 18^{\prime} 59^{\prime \prime} \mathrm{N}, 20^{\circ} 14^{\prime} 24^{\prime \prime} \mathrm{W}\right.$ - water depth 
$10 \mathrm{~m}$ ). Details of the biogeochemistry and biology of Young Sound are given elsewhere (Rysgaard et al. 1998, 1999, Glud et al. 2000b, Sejr et al. 2000).

Basic measurements. Snow and ice thicknesses were measured at regular time intervals on triplicate ice cores (9 $\mathrm{cm}$ diameter) drilled with a MARK II coring system (Kovacs Enterprises, Lebanon, NH). The temperature at the center of the bottom $5 \mathrm{~cm}$ of each ice core was measured with a thermometer (Testo thermometer, Lenzkirch, Germany). After melting in the dark $\left(0^{\circ} \mathrm{C}\right)$, the water was GF/C filtered, and samples for nutrient determination were frozen $\left(-18^{\circ}\right)$ until analysis. Salinity of the melted sections was determined with a Guildine PORTASAL salinometer. Brine salinity was calculated according to Assur (1958). Concentrations of $\mathrm{NO}_{3}{ }^{-}+$ $\mathrm{NO}_{2}{ }^{-}$were determined according to the scheme of Braman \& Hendrix (1989). Phosphate and Si concentrations were determined by standard colorimetric methods as described by Grasshoff et al. (1983). The GF/C filters containing chl a were extracted in $96 \%$ ethanol (Jespersen \& Christoffersen 1987) and measured spectrophotometrically (Strickland \& Parsons 1972). On 17 June measurements of $\mathrm{chl} \mathrm{a}$ were performed at 4 to $10 \mathrm{~cm}$ intervals throughout the sea ice. Prevailing downwelling quantum irradiance (400 to $700 \mathrm{~nm}$ ) above and directly below the sea ice was measured (in $\mu \mathrm{mol}$ photons $\mathrm{m}^{-2} \mathrm{~s}^{-1}$ ) using a quantum sensor (LiCor Li-190SA, Lincoln, NE) and an underwater quantum sensor (LiCor LI-192A) connected to a light meter (LiCor LI-1000) on the ice surface. Alternatively, the calibrated irradiance sensor of the Diving-PAM (see below) was used.

Oxygen measurements. In situ measurements of oxygen concentration profiles were performed with a Clark-type oxygen microsensor (Revsbech 1989) mounted directly on a waterproof electronics cylinder containing a pA measuring circuit (Unisense Aps./KCDenmark, Silkeborg, Denmark). The microsensors had measuring tip diameters of 40 to $100 \mu \mathrm{m}$ and a stirring sensitivity of $<1 \%$ or $2 \%$ (Glud et al. 2000a). The complete microsensor/electronics unit was mounted on a motor driven spindle fixed to a metal tripod (Fig. 2). Sensor readout as well as motor control was performed with an electronics unit at the sea ice surface via a $50 \mathrm{~m}$ underwater cable. Sensor signals were stored on a battery-driven strip-chart recorder (Servogor 110-2, Germany). The oxygen microsensors were linearly calibrated from 0 readings in surface water made anoxic by addition of sodium dithionite and from readings in air-saturated seawater. Concentration profiles were obtained at the sea ice-water interface, a zone that covers the lower few millimeters of the bottom ice.

Fluorescence measurements. A waterproof PAM fluorometer equipped with a blue LED (Diving-PAM, Walz, Germany) was used for assessing the quantum yield of charge separation $\phi_{\mathrm{p}}$ in photosystem II (PSII)

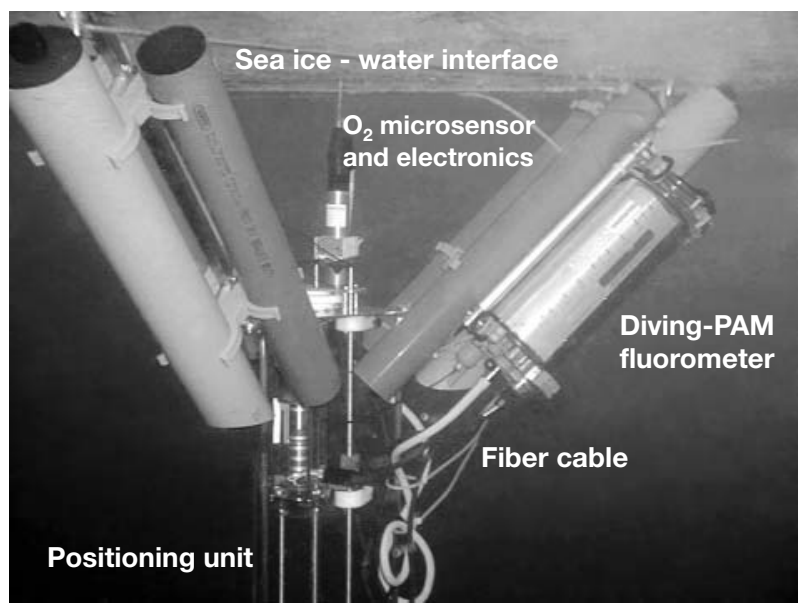

Fig. 2. In situ equipment for measuring sea ice algal fluorescence and oxygen profiles

in situ under ambient light conditions or during the measurement of light curves by application of defined actinic light levels via the measuring fiber cable of the instrument (Fig. 2). The internal halogen lamp of the Diving-PAM provided actinic light and saturation pulses. The irradiance (in $\mu \mathrm{mol}$ photons $\mathrm{m}^{-2} \mathrm{~s}^{-1}$ ) for different actinic light settings of the fluorometer was measured at the output of the immersed $8 \mathrm{~mm}$ fiber cable with an underwater quantum irradiance sensor (LiCor LI-192SA). The irradiance sensor of the Diving-PAM was calibrated against the underwater quantum irradiance sensor prior to the field experiments.

Rapid light curves (RLC) were measured by applying a sequence of increasing actinic irradiance in 9 discrete increments (Kühl et al. 2001). Each period of actinic light lasted for $10 \mathrm{~s}$, and a saturating pulse of white light ( 0.6 to $0.8 \mathrm{~s}$ at $\sim 5000 \mu \mathrm{mol}$ photons $\mathrm{m}^{-2} \mathrm{~s}^{-1}$ ) was then applied to determine $\phi_{\mathrm{p}}$. Relative electron transport rates (ETR) in RLC were calculated as the product of $\phi_{\mathrm{p}}$ and incident downwelling irradiance, $E_{\mathrm{d}}$ (PAR).

The Diving-PAM was operated manually by a SCUBA diver as a stand-alone instrument for frequent measurements of PSII quantum yield at the water-ice interface. These measurements covered the lower $\sim 1 \mathrm{~cm}$ of the bottom ice, including the sea ice-water interface. For such measurements, the fiber-optic cable of the instrument was positioned at the object of interest with one hand, and short-term measurements initiated by operating the instrument with the other hand. When measurements were to be made, the diver entered the sea ice hole and breathed just below it. Bubbles were carried away by the current, and the diver made measurements in the opposite direc- 
tion from the bubbles. When equipment was to be placed below the sea ice, the diver made sure that electrode and optical fibers were situated correctly before taking a deep breath and swimming into an area unaffected by bubbles, and placed the equipment there. He then left the measuring area before breathing again. For the seasonal investigation approximately 40 replicate measurements were obtained on each sampling date. Daily relative ETRs were calculated by multiplying measured relative ETRs at the time of measurement with a light factor (mean daily insolation divided by insolation at the time of measurement). For measurements of photosynthesis versus irradiance curves, the Diving-PAM was mounted on the tripod described above, and controlled from the ice surface (see Kühl et al. 2001). During measurements on the water-ice interface it was not possible to fully darken the ice volume monitored by the fiber cable due to diffuse downwelling light propagating through the ice. Consequently, we were unable to determine fluorescence under fully darkadapted conditions, i.e. $F_{0}$. Thus, the first yield measurement (i.e. the first data point on the RCL) was obtained at ambient irradiance, and the subsequent actinic light levels applied during the measurement were added to the ambient irradiance.

The relationship between photosynthetic rate $(P)$ and irradiance $(E)$, as represented by relative eETRs versus $E$, were determined in situ at Stn A on 3 dates (June 19, 21 and 27). A total of 5 to 15 in situ P-E measurements were performed on each date, and the parameters of the $P$ versus $E$ function were computed according to Platt et al. (1980) and Kühl et al. (2001).

Horizontal variations. On 23 June the diving-PAM was used in situ to investigate the heterogeneity of chl a $\left(F_{0}\right)$, irradiance (PAR) and algal activity $\left(\phi_{\mathrm{p}}\right)$ at the sea ice-water interface on different metric scales. The equipment was operated by a diver along a $15 \mathrm{~m}$ tape measure fastened in the sea ice; 5 measurements at $1 \mathrm{~cm}$ intervals were performed at Position $1 \mathrm{~m}$. The diver then moved to Position $1.1 \mathrm{~m}$ and made another 5 measurements at $1 \mathrm{~cm}$ intervals. This procedure was repeated at $2 \mathrm{~m}, 2.1 \mathrm{~m}, 3 \mathrm{~m}, 3.1 \mathrm{~m}, \ldots$, etc., and measurements were concluded at the $\sim 10 \mathrm{~m}$ position. All measurements were repeated along another tape measure positioned at right angles to the first. The mapping of horizontal patchiness was performed at Stns A, B and C.

The spatial autocorrelation (Legendre \& Legendre 1998) was used to analyze the 2-dimensional distribution of the variables: chl $a$, irradiance and $\phi_{\mathrm{p}}$. The autocorrelation was estimated by Moran's I (Moran 1950, Legendre \& Legendre 1998). This coefficient was calculated for each of the following classes of distance: 0-0.025 m, 0.025-0.25 m, 0.25-1 m, 1-5 m, 5-10 m,
10-50 m, 50-100 m, 100-200 m, 200-350 m, >350 m. Moran's $I$ and Pearson's correlation coefficient are closely related; positive and negative values indicate positive and negative autocorrelation, respectively. The individual autocorrelation coefficients estimated by Moran's $I$ were plotted in a spatial correlogram (Cliff \& Ord 1981), i.e. a graph with autocorrelation values plotted on the ordinate against distance classes among sampling sites on the abscissa. Distance classes were calculated by straight-line geographic distance. The spatial autocorrelation coefficients estimated by Moran's $I$ were tested for significance according to the method described in Legendre \& Legendre (1998). We used 2-tailed tests of significance since we did not have any a priori information on the signs of the spatial autocorrelations. When an individual autocorrelation coefficient exceeded the critical value (positive or negative), the null hypothesis of random spatial distribution (i.e. no spatial autocorrelation) was rejected at the specified level of significance. A significance level of $\mathrm{p}<0.05$ was used.

Fluorescence calibration. In order to convert the fluorescence signal from the Diving-PAM to actual chl a values in situ, the equipment was calibrated on both liquid and frozen samples of an algal culture (Ditylum brightwellii) containing different amounts of chl a $(0,1$, $5,10,50$ and $100 \mu \mathrm{g} \mathrm{l}^{-1}$ ); 5 replicate samples of each chl a concentration were measured with both the DIVING-PAM and a traditional technique (Jespersen \& Christoffersen 1987). Chlorophyll a concentrations were also measured on intact ice samples (area $22 \mathrm{~cm}^{2}$, thickness $4 \mathrm{~cm}$ ) collected by divers at regular time intervals during the field campaign.

To convert the data of relative ETRs from the DivingPAM to primary production rates, we performed a calibration experiment in which algal productivity was also measured with the ${ }^{14} \mathrm{C}$ technique (SteemanNielsen 1952). On 30 June, $\sim 40$ cores $(5.2 \mathrm{~cm}$ in diameter) of the 1 to $3 \mathrm{~cm}$ lower sea ice surface were collected by divers $10 \mathrm{~m}$ from the hole in the sea ice. The cores were brought back to the surface where they were homogenized and mixed without exposure to ambient light. The homogenized sea ice was distributed equally into $115 \mathrm{ml}$ glass bottles each containing $50 \mathrm{ml}$ filtered $(0.2 \mu \mathrm{m})$ water from the ice-water interface. After addition of $4 \mu \mathrm{Ci} \mathrm{H}^{14} \mathrm{CO}_{3}$ to both light and dark bottles ( 3 light bottles to 1 dark bottle), the bottles were suspended from the sea ice hole at different depths representing 5 different light intensities (6 to $80 \mu \mathrm{mol}$ photons $\mathrm{m}^{-2} \mathrm{~s}^{-1}$. The samples were incubated for $2 \mathrm{~h}$. After incubation, the bottles were kept in the dark until filtration, which was performed within $2 \mathrm{~h}$. The entire content of each bottle was filtered onto $25 \mathrm{~mm}$ GF/C filters. The filters were transferred to scintillation vials together with $200 \mu \mathrm{l}$ of $1 \mathrm{~N} \mathrm{HCl}$ be- 
fore they were frozen until counting. Excess inorganic ${ }^{14} \mathrm{C}$ was removed by directing a flow of air into the vials before addition of scintillation fluid. Samples were counted on a liquid scintillation analyzer (Packard 1900TR). The concentration of dissolved inorganic carbon (DIC) was measured on triplicate parallel glass bottles containing amounts of homogenized sea ice and filtered surface water similar to those used in the ${ }^{14} \mathrm{C}$ incubations. DIC was analyzed on a $\mathrm{CO}_{2}$ analyzer (Coulometer CM5012, UIC Inc., Joliet, IL, USA). Carbon fixation was derived after subtracting the dark fixation values.

In parallel to the ${ }^{14} \mathrm{C}$ incubation, 5 in situ DivingPAM measurements of RLCs were performed at the same location where samples were collected for the ${ }^{14} \mathrm{C}$ calibration measurements.

\section{RESULTS}

\section{Physical and chemical variables}

Prevailing downwelling quantum irradiance (400 to $700 \mathrm{~nm}$ ) above the sea ice during the investigation period varied between $\sim 100$ and $1400 \mu \mathrm{mol}$ photons $\mathrm{m}^{-2} \mathrm{~s}^{-1}$ with an average diurnal irradiance of 280 to $700 \mu \mathrm{mol}$ photons $\mathrm{m}^{-2} \mathrm{~s}^{-1}$ during overcast and sunny days, respectively (Fig. 3a). Lowered mean irradiance was observed during 2 stormy periods around 16 June and 25 June. Prevailing downwelling quantum irradiance directly below the sea ice varied between 0.2 and $20 \mu \mathrm{mol}$ photons $\mathrm{m}^{-2} \mathrm{~s}^{-1}$ during our study, with an average diurnal irradiance of 2 to $9 \mu \mathrm{mol}$ photons $\mathrm{m}^{-2} \mathrm{~s}^{-1}$. A steep increase in light penetration was observed in early to mid June due to a decrease in snow cover. From June to early July, light penetration through the ice increased, and consequently the irradiance below the ice increased from 0.3 to $1.4 \%$ of incident surface irradiance (Fig. 3b). Mean diurnal air temperatures varied from -0.2 to $7.5^{\circ} \mathrm{C}$, with higher temperatures at the end of the study period, while the temperature below the sea ice increased from -1.2 to $-0.4^{\circ} \mathrm{C}$ (Fig. 3c).

In early June, the sea ice was covered by $30 \mathrm{~cm}$ of dry snow, which melted and gradually created small ponds covering areas of 1 to $100 \mathrm{~m}^{2}$. Water drained through the sea ice in 2 distinct periods, between 9 and 14 June and again between 30 June and 1 July. In the first period, a $15 \mathrm{~cm}$ freshwater layer below the snow suddenly drained through the sea ice (Fig. 3d). This water layer was created in late May to early June due to a sudden increase in temperature (cf. monitoring data from Zackenberg Ecological Research Operations). The second drainage period was more dramatic and resulted in the formation of 10 to $20 \mathrm{~cm}$ icicles

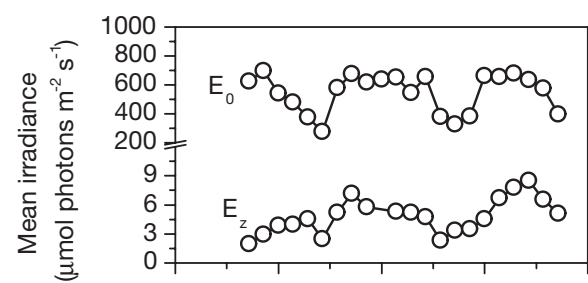

(a)

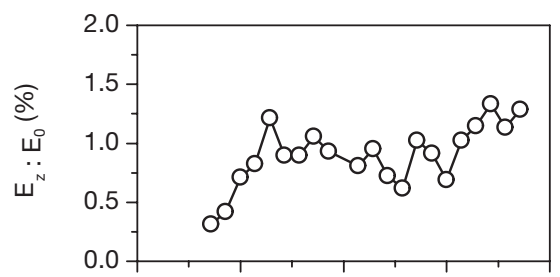

(b)

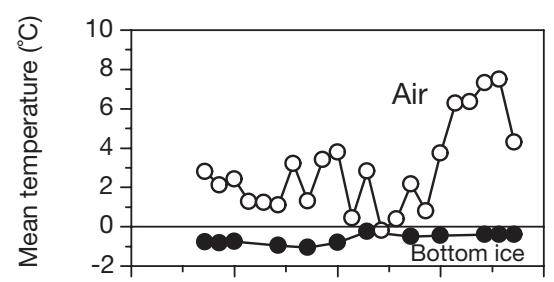

(c)

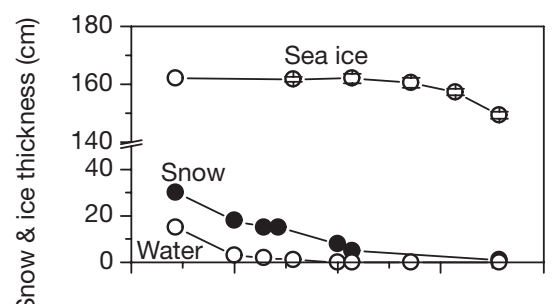

(d)

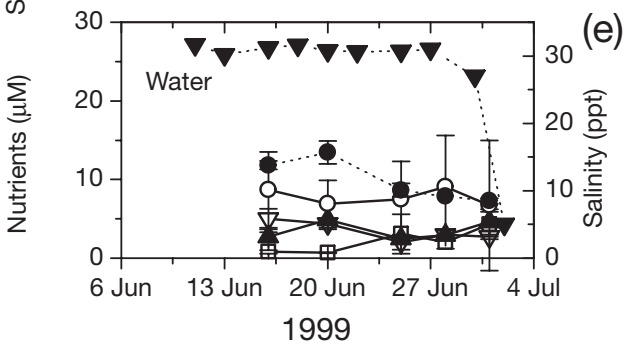

Fig. 3. (a) Mean diurnal irradiance in air $\left(E_{z}\right)$ and below sea ice $\left(E_{0}\right)$, (b) irradiance below sea ice in relation to irradiance in air, (c) mean diurnal temperature in air and in bottom ice, (d) sea ice and snow thickness, the freshwater layer overlying the ice (under the snow), and (e) salinity immediately below sea ice $(\boldsymbol{\nabla})$ and in brine $(\bullet)$ and nutrients $\left(\nabla, \mathrm{NO}_{3}^{-} ; \mathrm{O}, \mathrm{NH}_{4}{ }^{+}\right.$; $\square, \mathrm{PO}_{4}{ }^{3-} ; \mathbf{\Lambda}, \mathrm{Si}$ ) in bottom ice brine during the investigation period

below the sea ice. At the end of the study period, it was difficult to distinguish snow from sea ice and, if any, only a few centimeters of snow was left (Fig. 3d).

Salinity near the sea ice-water interface $(0$ to $10 \mathrm{~cm}$ ) varied around $31 \%$ until 30 June when the salinity suddenly decreased to $5 \%$ due to the draining of freshwater melt ponds and due to freshwater input from the Zackenberg River (Fig. 3e). The brine salinity varied from 8 to $15 \%$ and was lower than the salinity of 

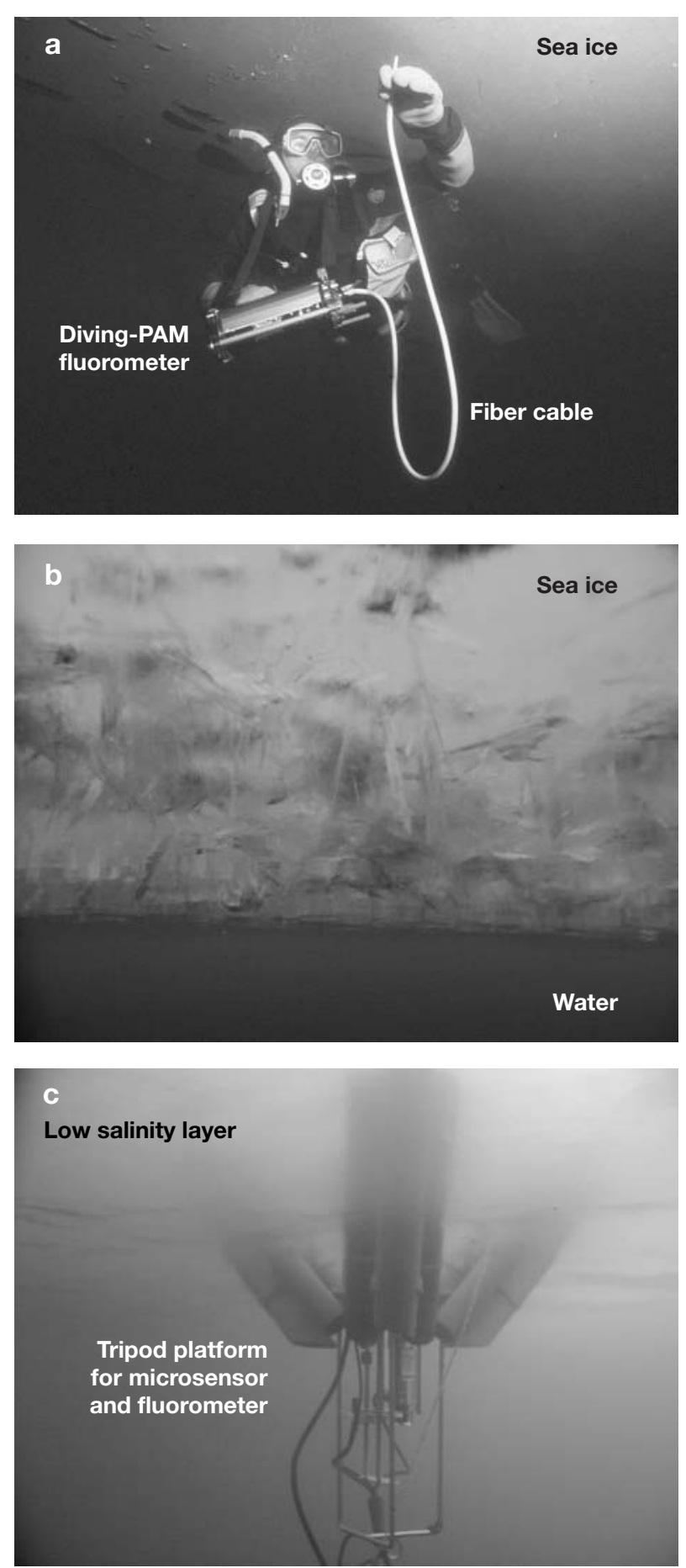

Fig. 4. Underwater photo of sea ice (a) 13 June, (b) 14 June and (c) 2 July

the underlying water due to active melting of sea ice during the study period. Brine concentrations of Si varied from 2 to $4 \mu \mathrm{M}, \mathrm{NO}_{3}{ }^{-}$from 2 to $5 \mu \mathrm{M}, \mathrm{NH}_{4}{ }^{+}$from 7 to $10 \mu \mathrm{M}$, and $\mathrm{PO}_{4}{ }^{3-}$ from 1 to $4 \mu \mathrm{M}$ throughout the study period (Fig. 3e).

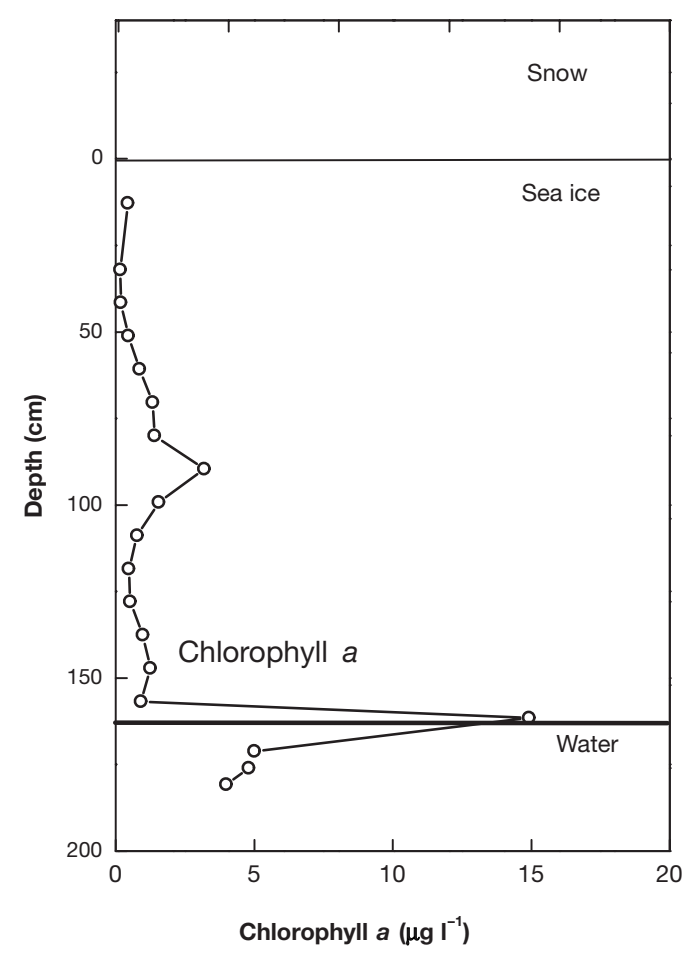

Fig. 5. Chlorophyll a profile in sea ice, 17 June

The bottom ice was very dynamic (Fig. 4). The underside of the sea ice was smooth and solid on 13 June (Fig. 4a). However, the day after, presumably due to drainage of the $15 \mathrm{~cm}$ freshwater layer, a sub-ice crystal layer of 5 to $15 \mathrm{~cm}$ was created (Fig. 4b). After 14 June, this layer varied in thickness and distribution. Some days it was absent and the lower sea ice surface was solid and smooth as observed on 13 June. However, between 30 June and 1 July freshwater input from the melt ponds and river discharge resulted in the formation of icicles and a very low salinity in the upper $0.5 \mathrm{~m}$ of the water column (Fig. $4 \mathrm{c}$ ).

\section{Vertical distribution of algal biomass and oxygen}

The present study focuses on sea ice algal biomass and productivity within the lower centimeters of the sea ice, where a maximum concentration of chl a was observed (Fig. 5). However, chl a was also present further inside the sea ice matrix, with peak concentrations of $\sim 3 \mu \mathrm{g} \mathrm{chl} \mathrm{a} \mathrm{l}^{-1}$. On 17 June, the area-integrated

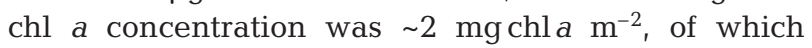
$0.6 \mathrm{mg} \mathrm{chl} \mathrm{a} \mathrm{m}^{-2}(30 \%)$ could be attributed to the lower $4 \mathrm{~cm}$ of the sea ice.

Sea ice algae inhabited the lowermost $1 \mathrm{~mm}$ of the porous ice layer, which exhibited oxygen supersaturation of 150 to $200 \%$ relative to ambient sea water levels 


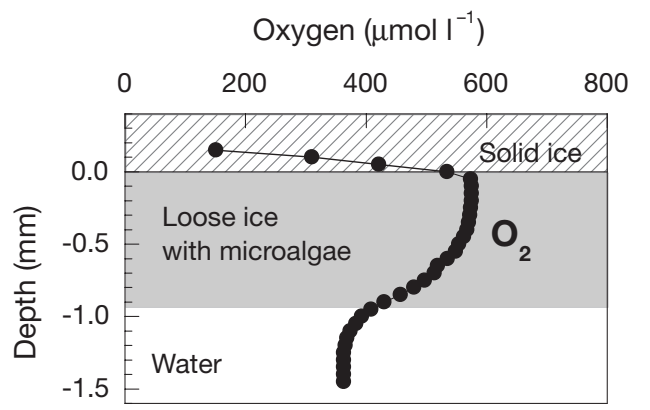

Fig. 6. Oxygen concentration profile at the sea ice-water interface, 25 June

(Fig. 6). The steep decrease in the $\mathrm{O}_{2}$ concentration in the solid ice was mainly caused by limited diffusion of $\mathrm{O}_{2}$ towards the sensor tip. Thus, the alterations in this micro-scale $\mathrm{O}_{2}$ concentration were affected by the algae. However, the $\mathrm{O}_{2}$ dynamics inside the sea ice matrix were found to be very complex and strongly influenced by the physical and chemical properties caused by freezing and melting processes. Therefore, there was no simple correlation between net photosynthesis estimated from $\mathrm{O}_{2}$ microprofiles and the other production estimates. The dynamics of $\mathrm{O}_{2}$ within sea ice will be discussed in further detail elsewhere (Kühl et al. 2001).

\section{Fluorescence calibration}

PAM-based measurement of relative ETR correlated well with productivity measured by the traditional ${ }^{14} \mathrm{C}$ technique at different light intensities (Fig. 7). Scaling down relative ETR by a factor of 20 gave values of ${ }^{14} \mathrm{C}$ in micrograms of carbon per liter per hour. At the observed in situ light intensities ( 0.2 to $20 \mu \mathrm{mol}$ photons $\left.\mathrm{m}^{-2} \mathrm{~s}^{-1}\right)$, the carbon assimilation was low (0.1 to $\left.0.2 \mu \mathrm{g} \mathrm{C}^{-1} \mathrm{~h}^{-1}\right)$. Furthermore, fluorescence measurement $\left(F_{0}\right)$ correlated well with chl a concentration. No significant difference between frozen and liquid samples was observed in the laboratory where the chl a concentration could be described by: chl $a=0.29 \times F_{0}$ -2.26 , with $r^{2}=0.998$. In situ fluorescence measurements also corresponded well with the parallel chl a measurements $\left(r^{2}=0.954\right)$ as shown in Fig. $8 b$.

\section{Seasonal variations}

Combined in situ data on downwelling irradiance $\left(E_{\mathrm{d}}\right)$, fluorescence $\left(F_{0}\right)$, quantum yield $\left(\phi_{\mathrm{p}}\right)$ and relative ETRs throughout the investigation period are presented in Fig. 8. The difference between irradiances depicted in Figs $3 a$ \& $8 a$ is due to the fact that mea-

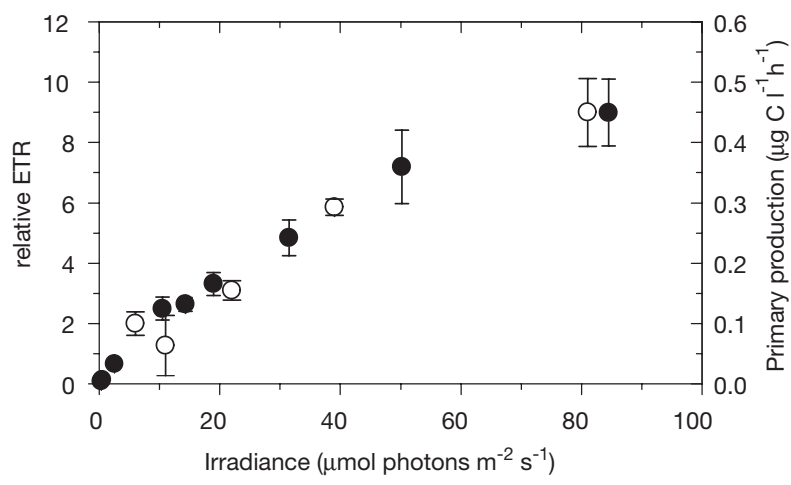

Fig. 7. Primary production $(O)$ and relative electron transport rate $(E T R, \bullet)$ versus irradiance. Error bars represent standard error $(n=5)$
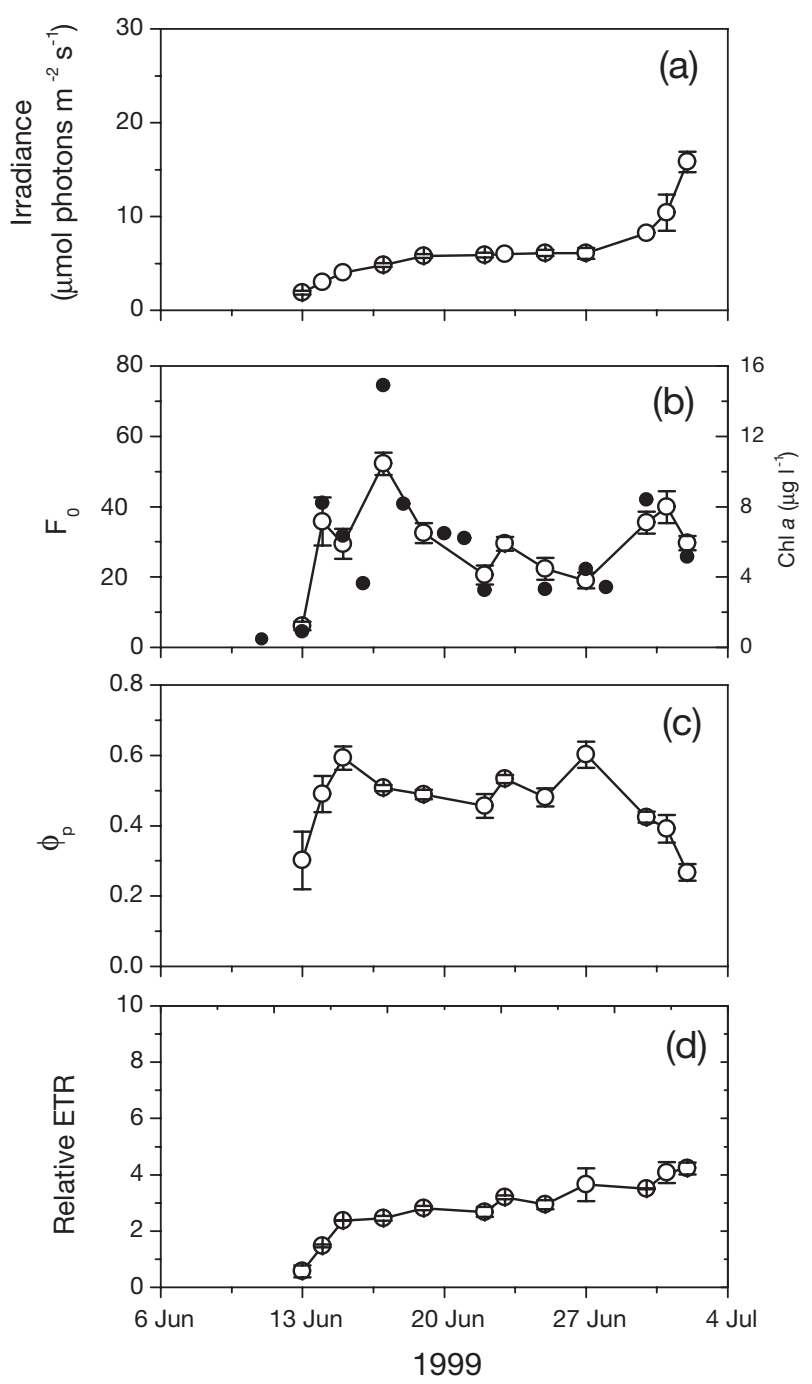

Fig. 8. Seasonal variation in (a) irradiance at measuring time $\left(E_{\mathrm{z}}\right)$; (b) fluorescence values $\left(F_{0}, O\right)$ and chl a $(\bullet)$; (c) quantum yield of photochemical energy conversion $\left(\phi_{\mathrm{p}}\right)$; and (d) relative electron transport rate (ETR). Error bars represent standard error of the mean $(n=40)$ 


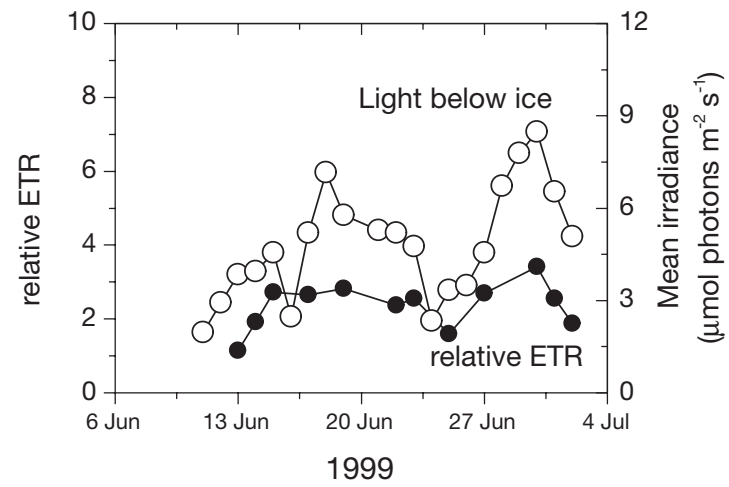

Fig. 9. Mean diurnal light irradiance below sea ice $(O)$ and relative electron transport rate $(E T R, \bullet)$ corrected to daily activity

surements in Fig. 3 represent average diurnal values while Fig. 8a represents values at the time of measuring. Two distinct peaks in $F_{0}$ and chl a concentrations were observed (Fig. 8b). Maximum chl a concentrations were observed on 17 June, when $\sim 15 \mu \mathrm{g} \mathrm{chl} \mathrm{a} \mathrm{l}^{-1}$ was measured at the sea ice-water interface (lower $4 \mathrm{~cm}$ )

A doubling of the quantum yield of photochemical energy conversion $\left(\phi_{\mathrm{p}}\right)$ was observed in the first $3 \mathrm{~d}$ of the campaign (Fig. 8c). After this period, $\phi_{\mathrm{p}}$ remained almost constant until 30 June when it decreased to previous levels. Finally, the relative ETRs
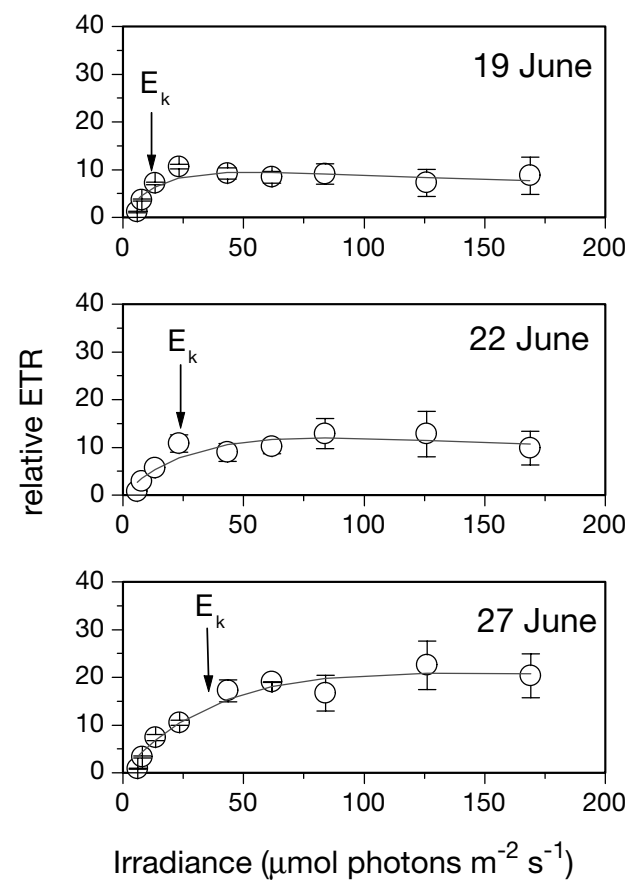

Fig. 10. Relative electron transport rate (ETR) versus irradiance for 3 different dates calculated as the product of $\phi_{\mathrm{p}}$ and incident downwelling irradiance $\left(E_{\mathrm{d}}\right)$ at the time of measurement increased throughout the study period (Fig. 8d). However, when adjusting the relative ETRs to daily insolation (see 'Materials and methods'), the relative ETRs followed the mean diurnal light regime throughout the campaign period (Fig. 9). The calibration data between carbon assimilation and relative electron transport (Fig. 7), combined with the seasonal measurements of relative electron transport (Fig. 9), were used to estimate the amount of carbon being fixed by the sea ice algal community during June and July. Integration based on the data from Fig. 9 showed that sea ice algal productivity associated with the underside of the sea ice accounted for 2 to $3 \mathrm{mgC}$ $\mathrm{m}^{-2}$. Since snow depth had been $>40 \mathrm{~cm}$ since early winter (monitoring data from Zackenberg Ecological Research Operations), it is doubtful that sea ice algal production before June could have contributed further to annual production. Hence, annual sea ice algal production in the sound was low.

Despite low algal activity it was possible to obtain in situ data for the $P$ - $E$ relationship, i.e. relative ETR versus irradiance, on 19, 22 and 27 June with the DivingPAM (Fig. 10). Within that period, the light adaptation index $\left(E_{\mathrm{k}}\right)$ for the sea ice algal community increased from 12 to $35 \mu \mathrm{mol}$ photons $\mathrm{m}^{-2} \mathrm{~s}^{-1}$.

\section{Horizontal variations}

On 23 June, 600 measurements of both chlorophyll fluorescence $\left(F_{0}\right)$, irradiance $\left(E_{\mathrm{d}}\right)$, and of algal activity $\left(\phi_{\mathrm{p}}\right)$ at the sea ice-water interface were obtained in situ on different metric scales to describe the horizontal 2-dimensional distribution of these variables. As an example of the data obtained, the chlorophyll fluorescence at the 3 different stations is shown in Fig. 11. Minimum and maximum chlorophyll fluorescence were 0 and 120 ( 0 to $32.5 \mu \mathrm{g}$ chl a $\mathrm{l}^{-1}$ ), respectively, corresponding to a mean $F_{0}$ of $22.4\left(4.2 \mu \mathrm{g} \mathrm{chl} \mathrm{a} \mathrm{^{-1 }}\right)$

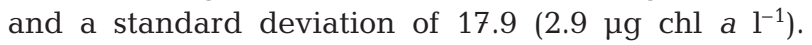
Moran's I was used to estimate the spatial autocorrelation within the dataset (Fig. 12). All values except the $>350 \mathrm{~m}$ classes of distances are significant. The change from positive to negative values of Moran's $I$ for chlorophyll fluorescence occurred from the $5 \mathrm{~m}$ class of distances to the $10 \mathrm{~m}$ class of distances. This indicates that the average radius of the microalgal patches was probably between 5 and $10 \mathrm{~m}$, where the first 0 of the correlograms is observed. In contrast, the average radius of the irradiance and algal activity patches was between 50 and $100 \mathrm{~m}$ where the first change from positive to negative values of Moran's $I$ occurred for $E_{\mathrm{d}}$ and $\phi_{\mathrm{p}}$. 

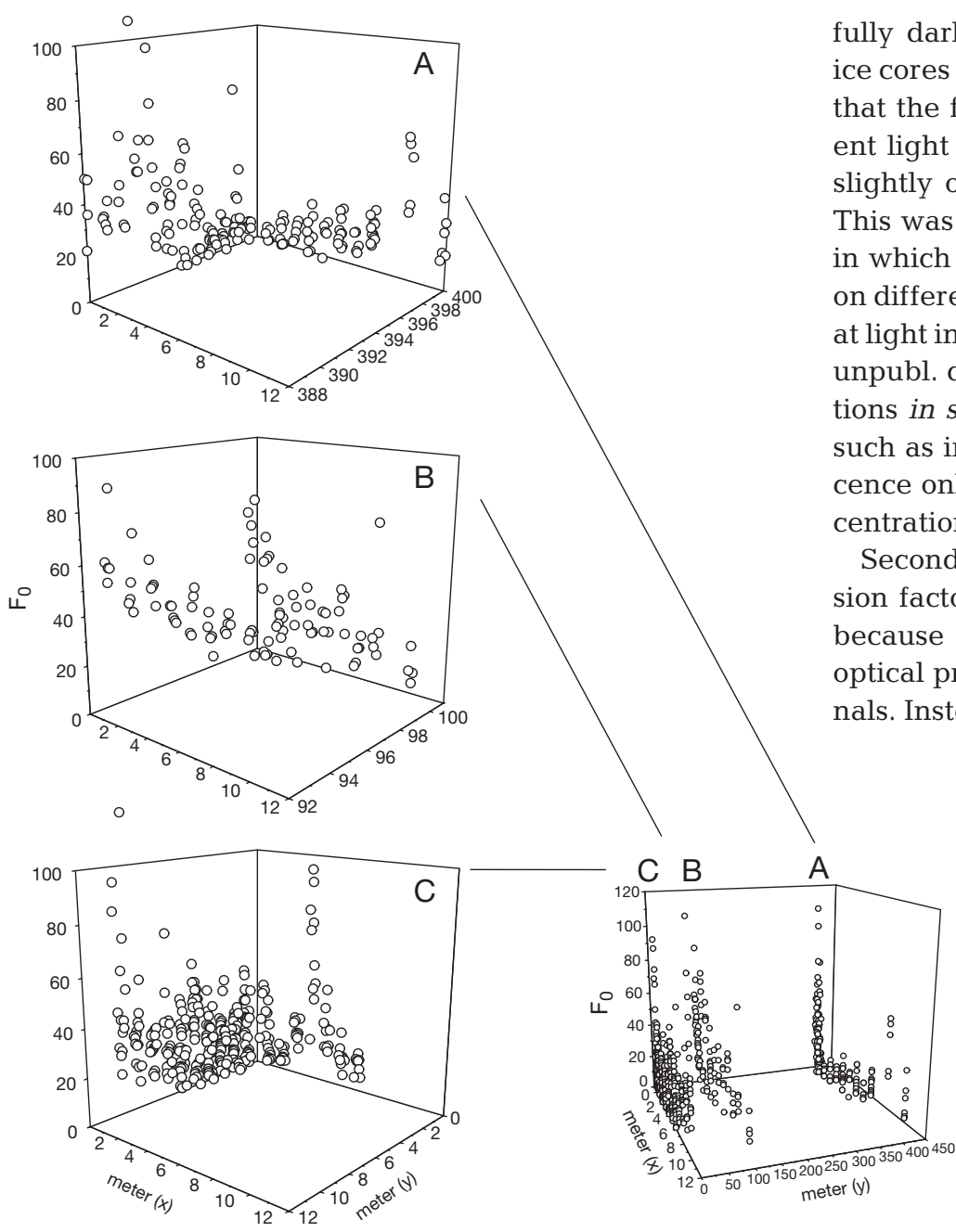

Fig. 11. Spatial heterogeneity in algal biomass $\left(F_{0}\right)$ at Stns $A, B$ and $C$ obtained on 23 June. The lower right panel shows the distance between stations, and $\mathrm{A}, \mathrm{B}$ and $\mathrm{C}$ show the 2-dimensional variation in $F_{0}(\mathrm{chl}$ a) fully darkened. Several dark measurements of $F_{0}$ on ice cores collected throughout the study period showed that the fluorescence signal obtained when the ambient light intensity was $<30 \mu \mathrm{mol}$ photons $\mathrm{m}^{-2} \mathrm{~s}^{-1}$ only slightly overestimated the true $F_{0}$ value ( $5 \%$ to $7 \%$ ). This was further supported by laboratory experiments in which true $F_{0}$ values could be obtained in darkness on different algal biomasses ( 5 to $220 \mathrm{mg} \mathrm{chl} \mathrm{a} \mathrm{m}^{-2}$ ) and at light intensities $<50 \mu \mathrm{mol}$ photons $\mathrm{m}^{-2} \mathrm{~s}^{-1}$ (Glud et al. unpubl. data). Thus, when measuring chl a concentrations in situ, where the ambient light intensity is low, such as in sea ice communities, the measured fluorescence only slightly overestimates the actual chl a concentrations.

Secondly, it is not possible to use a universal conversion factor between relative ETR and photosynthesis, because different algal communities and different optical properties of the sea ice will give different signals. Instead, experiments should be performed where measurements from the Diving-PAM are calibrated with traditional techniques (e.g. ${ }^{14} \mathrm{C}$ ). A direct conversion of quantum yield or ETR to primary production is still impossible. There are too many unknown quantities and processes in our understanding of quantum yield, photosynthetic quotient electron generation and flow from PSII to $\mathrm{CO}_{2}$ fixing enzymes such as Rubisco or PEPcarboxilase (e.g. Schofield et al. 1995). Nevertheless, a good correlation between oxygen production and quantum yield is possible because of the relatively strong connection between charge separation in PSII by water splitting and simultaneous oxygen production. One oxygen molecule is pro-

\section{DISCUSSION}

\section{Diving-PAM technique}

Successful in situ measurements were obtained with the new DIVING-PAM technique during this investigation, although light intensities and sea ice algal biomass and production at the sea ice-water interface were low. However, several precautions have to be taken when converting the obtained measurements to actual algal biomass and photosynthetic activity. Firstly, when approximating chl a concentrations with measurements of fluorescence obtained under conditions in which the algae in their natural habitat cannot be fully dark-adapted, it is necessary to check that the fluorescence signal is not dramatically altered when performing measurements on ice cores that can be

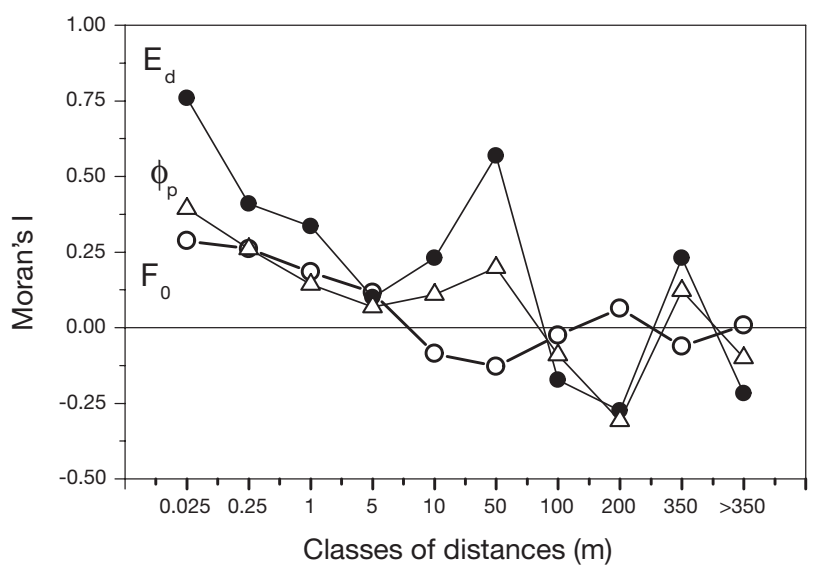

Fig. 12. Moran's $I$ as a function of classes of distances between sites for irradiance $\left(E_{\mathrm{d}}, \bullet\right)$, algal activity $\left(\phi_{\mathrm{p}}, \Delta\right)$, and chlorophyll fluorescence $\left(F_{0}, 0\right)$ 
duced when 4 electrons are generated in PSII. However, despite these constraints in our understanding the ${ }^{14} \mathrm{C}$ measurements are comparable with the PAM measurements over all applied irradiances (Fig. 7). The in situ calibration experiments were supplemented with laboratory experiments based on much higher

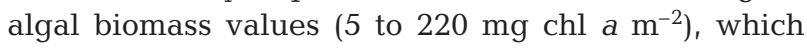
showed that the 2 techniques correlate well over a wide range of algal biomass values (Glud et al. unpubl. data).

Thirdly, another weakness of the Diving-PAM equipment is that measurements, for optical reasons, include only the lower $\sim 1 \mathrm{~cm}$ of the sea ice and, thus, do not take into account the sea ice algal communities further inside the sea ice matrix. Recently, it has been reported that a large fraction of the sea ice biota is in fact located within the interior of the sea ice (Mock \& Gradinger 1999). Thus, since our Diving-PAM measurements only consider the lower part of the ice, the overall algal abundance and production are underestimated. However, the technique may still be able to detect algal distribution and activity further inside the sea ice if measurements are performed on sections of whole ice cores.

\section{Seasonal variations}

Two periods of elevated chl a concentrations and photosynthetic activity at the ice-water interface were observed (Figs. 8b \& 9). A very low algal biomass was found on 13 June (Fig. 8b), when the lower sea ice surface was smooth and solid (Fig. 4a) and the mean diurnal irradiance below the sea ice was $\sim 3 \mu \mathrm{mol}$ photons $\mathrm{m}^{-2} \mathrm{~s}^{-1}$. However, a steep increase in algal activity and biomass was observed from 13 to 17 June (Fig. 9), when the sub-ice crystal layer was formed (Fig. 4b) due to an increase of diurnal irradiance $\sim 7 \mu \mathrm{mol}$ photons $\mathrm{m}^{-2} \mathrm{~s}^{-1}$, while maximum irradiance at noon was $\sim 17 \mu \mathrm{mol}$ photons $\mathrm{m}^{-2} \mathrm{~s}^{-1}$. Although algal activity remained almost constant from 17 to 24 June while insolation was low, the chl a level decreased to $1 / 3$ of its maximum value within that period. The decrease in algal biomass between 14 and 24 June was associated with the deterioration of the sub-ice crystal layer, leading to a loss of algae to the water column. This was evident from sediment traps placed $2 \mathrm{~m}$ below the sea ice (B. Thamdrup unpubl. results). However, a second increase in both algal activity and biomass occurred after 27 June, when light increased to a mean diurnal irradiance of $9 \mu \mathrm{mol}$ photons $\mathrm{m}^{-2} \mathrm{~s}^{-1}$ with up to $20 \mu \mathrm{mol}$ photons $\mathrm{m}^{-2} \mathrm{~s}^{-1}$ around noon. These observations are very similar to findings from Manitounuk Sound, where algal productivity began to increase when light reached a critical value of $\sim 7 \mu \mathrm{mol}$ photons $\mathrm{m}^{-2} \mathrm{~s}^{-1}$ and where biomass only accumulated when light reached $\sim 20 \mu \mathrm{mol}$ photons $\mathrm{m}^{-2} \mathrm{~s}^{-1}$ (Gosselin et al. 1985). Thus, our results from Young Sound support the general finding that photosynthesis at the ice-water interface starts at very low light intensities (Horner \& Schrader 1982, Smith et al. 1987, Robinson et al. 1998, Haecky \& Andersson 1999).

Freshwater inputs between 30 June and 1 July caused algal activity and biomass to decrease once again (Figs. 3e, 4c, 8b \& 9). Hence, it is doubtful whether sea ice algal activity and biomass would have had sufficient time to develop in Young Sound after 2 July because low salinities have been shown to inhibit algal production in ice (Bates \& Cota 1986). Usually, a freshwater lens (1 to $5 \%$ ) created by active melting of the sea ice and freshwater input from the Zackenberg River prevails from the end of June until the ice breaks up in mid July (Rysgaard et al. 1999).

In the study period, light alone accounted for $60 \%$ of the variance in algal activity $\left(r^{2}=0.6 ; p=0.004\right)$. In contrast, we found no significant correlation between nitrogen $\left(\mathrm{r}^{2}=0.2 ; \mathrm{p}=0,32\right)$, phosphate $\left(\mathrm{r}^{2}<0.07 ; \mathrm{p}=\right.$ $0.66)$ or silicate $\left(\mathrm{r}^{2}<0.07 ; \mathrm{p}=0.68\right)$ and algal activity. Thus, the combination of low light levels caused by snow and periods of low insolation, the physical disturbance of the sea ice-water interface and low salinities seem to be the main controlling factors of algal activity and biomass in the sound.

The adaptation of algae to light in Young Sound was further elucidated by measurement of $P$ - $E$ curves on 3 separate dates (Fig. 10). The index of light adaptation $\left(E_{\mathrm{k}}\right)$ for the sea ice algal community increased from 12 to $35 \mu \mathrm{mol}$ photons $\mathrm{m}^{-2} \mathrm{~s}^{-1}$, and was comparable to the prevailing downwelling quantum irradiance directly below the sea ice $\left(E_{\mathrm{z}}\right)$, which also increased over the period of investigation ( 0.2 to $20 \mu \mathrm{mol}$ photons $\mathrm{m}^{-2} \mathrm{~s}^{-1}$ ). The reason $E_{\mathrm{k}}$ was slightly higher than $E_{\mathrm{z}}$ may be that $E_{\mathrm{z}}$ was not measured directly within the sea ice layer but a few centimeters below the sea ice-water interface, and the actual amount of light available to the algae may thus have been underestimated. How large this underestimation is awaits detailed measurements of scalar irradiance in the matrix of sea ice and microalgae.

\section{Horizontal variations}

Strong patchiness in the distribution of sea ice algae and light was observed in Young Sound. Algal activity followed the light regime below the sea ice and patches with an average radius of from 50 to $100 \mathrm{~m}$ could describe both. However, the horizontal variation in light and algal activity differed from the horizontal variation in algal biomass, which in our study was dis- 
tributed in smaller patches of about 5 to $10 \mathrm{~m}$. The reason for the difference in patchiness may be due to grazing or different algal activity in different patches, or the result of algal biomass being removed through physical disturbance or the inhibition of algae by salinity fluctuations caused by melting. Another explanation may be that the biomass did not respond as rapidly to improved light conditions as the algal activity and that the difference between patch sizes reflects a variation with time. Our findings are comparable to earlier investigations of the horizontal variation in algal biomass carried out by Gosselin et al. (1986), which suggested that the snow/ice cover thickness was most important in controlling algal patch sizes of $O(10 \mathrm{~m})$. Finally, our observations also show that the variation in light, as well as in algal biomass and activity, on scales from 0.025 to $5 \mathrm{~m}$ in radius is small. Hence, in order to extrapolate measurements of algal biomass and activity to Young Sound, it is necessary to include measurements over distances of at least $100 \mathrm{~m}$.

The biomass and production of sea ice algae in Young Sound are comparable to measurements performed further offshore in the Greenland Sea (Gradinger et al. 1999, Mock \& Gradinger 1999). Gradinger et al. (1999) suggested that the biomass in pack ice is much lower that in fast-ice areas due to lower nutrient supply, different physical constraints (ice temperature, brine salinity, radiation) or biological interactions (grazing and growth rates). However, when comparing the ice algal biomass in Young Sound with other coastal fast-ice areas at the same northern latitude characterized by almost the same conditions of temperature, ice and snow thickness, irradiance and nutrient concentrations (Cota et al. 1991), the algal biomass is much lower in Young Sound. Furthermore, the low algal biomass does not seem to be caused by high grazing pressure, since the biomass of grazers was not exceptionally high in Young Sound but comparable to other locations (Rysgaard et al. 1999, Levinsen et al. 2000). Therefore, we suggest that the combination of low insolation during cloudy periods and physical disturbances of the sea ice matrix induced by freshwater inputs hindered the build-up of the ice algal community in Young Sound. Integrated over the measuring period ice algae only accounted for $<1 \%$ of the pelagic primary production measured earlier at the same location and time interval (Rysgaard et al. 1999).

Acknowledgements. The study was financially supported by the Danish Natural Science Research Councils (Contract No. 9700224 and 9700549). We wish to thank the Danish Military Division SIRIUS for its hospitality and the Danish Polar Center for help with logistics. Søren E. Larsen is thanked for help with the statistical calculations. Thomas Rasmussen is acknowledged for diving assistance. Anna Haxen is thanked for linguistic corrections.

\section{LITERATURE CITED}

Assur A (1958) Composition of sea ice and its tensile strength. Publ Natl Res Coun Wash 589:106-138

Bates SS, Cota GF (1986) Fluorescence induction and photosynthetic responses of Arctic ice algae to sample treatment and salinity. J Phycol 22:421-429

Braman RS, Hendrix SA (1989) Nanogram nitrite and nitrate determination in environmental and biological meterials by vanadium (III) reduction with chemiluminescence detection. Anal Chem 61:2715-2718

Cliff AD, Ord JK (1981) Spatial processes: models and applications. Pion Limited, London

Cota GF, Smith REH (1991) Ecology of bottom ice algae. II. Dynamics, distributions and productivity. J Mar Sys 2: 279-295

Cota GF, Legendre L, Gosselin M, Ingram RG (1991) Ecology of bottom ice algae. I. Environmental controls and variability. J Mar Sys 2:257-277

Glud RN, Gundersen JK, Ramsing NB (2000a) Electrochemical and optical oxygen microsensors for in situ measurements. In: Buffle J, Horvai G (eds) In situ monitoring of aquatic systems: chemical analysis and speciation. John Wiley \& Sons Ltd., Chichester

Glud RN, Risgaard-Petersen N, Thamdrup B, Fossing H, Rysgaard S (2000b) Benthic carbon mineralization in a highArctic sound (Young Sound, NE-Greenland). Mar Ecol Prog Ser 206:59-71

Gosselin M, Legendre L, Demers S, Ingram RG (1985) Responses of sea-ice microalgae to climatic and fortnightly tidal energy inputs (Manitounuk Sound, Hudson Bay). Can J Fish Aquat Sci 42:999-1006

Gosselin M, Legendre L, Therriault J-C, Demers S, Rochet M (1986) Physical control of the horizontal patchiness of seaice microalgae. Mar Ecol Prog Ser 29:289-298

Gradinger R, Friedrich C, Spindler M (1999) Abundance, biomass and composition of the sea ice biota of the Greenland Sea pack ice. Deep-Sea Res II 46:1457-1472

Grasshoff K, Erhardt M, Kremling K (1983) Methods of seawater analysis, 2 nd revised and extended version. Verlage Chemie, Weinheim

Haecky P, Andersson A (1999) Primary and bacterial production in sea ice in the northern Baltic Sea. Aquat Microb Ecol 20:107-118

Horner R, Schrader GC (1982) Relative contributions of ice algae, phytoplankton, and benthic microalgae to primary production in nearshore regions of the Beaufort Sea. Arctic 35:485-503

Jespersen AM, Christoffersen K (1987) Measurements of chlorophyll-a from phytoplankton using ethanol as extraction solvent. Arch Hydrobiol 109:445-454

Kühl M, Glud RN, Borum J, Rysgaard S (2001) Photosynthetic performance of surface-associated algae below sea ice as measured with pulse amplitude modulated (PAM) fluorometer and $\mathrm{O}_{2}$ microsensors. Mar Ecol Prog Ser 223:25-38

Legendre P, Legendre L (1998) Developments in environmental ecology, 20. Numerical ecology, 2nd English edn. Elsevier Science BV, Amsterdam

Levinsen H, Turner JT, Nielsen TG, Hansen BW (2000) On the trophic coupling between protists and copepods in arctic marine ecosystems. Mar Ecol Prog Ser 204:65-77

McMinn A, Ashworth C, Ryan K-G (2000) In situ net primary productivity of an Antarctic fast ice bottom algal community. Aquat Microb Ecol 21:177-185

Mock T, Gradinger R (1999) Determination of Arctic ice algal production with a new in situ incubation technique. Mar Ecol Prog Ser 177:15-26 
Moran PAP (1950) Notes on continuous stochastic phenomena. Biometrika 37:17-23

Platt T, Gallegos CL, Harrison WG (1980) Photoinhibition of photosynthesis in natural assemblages of marine phytoplankton. J Mar Res 38:687-701

Revsbech NP (1989) An oxygen microelectrode with a guard cathode. Limnol Oceanogr 4:474-478

Robinson DH, Arrigo KR, Kolber Z, Gosselin M, Sullivan CW (1998) Phytophysiological evidence of nutrient limitation of platelet ice algae in McMurdo Sound, Antarctica. J Phycol 34:788-797

Rysgaard S, Thamdrup B, Risgaard-Petersen N, Fossing H, Berg P, Christensen PB, Dalsgaard T (1998) Seasonal carbon and nutrient mineralization in a high-Arctic coastal marine sediment, Young Sound, Northeast Greenland. Mar Ecol Prog Ser 175:261-276

Rysgaard S, Nielsen TG, Hansen BW (1999) Seasonal variation in nutrients, pelagic primary production and grazing in a high-Arctic coastal marine ecosystem, Young Sound, Northeast Greenland. Mar Ecol Prog Ser 179:13-25

Editorial responsibility: Otto Kinne (Editor)

Oldendorf/Luhe, Germany
Schofield O, Kroon BMA, Prezelin BB (1995) Impact of ultraviolet-B radiation on photosystem-II activity and its relationship to the inhibition of carbon fixation rates for antarctic ice algae communities. J Phycol 31:703-715

Sejr MK, Jensen KT, Rysgaard S (2000) Macrozoobenthic community structure in a high-Arctic East Greenland Fjord. Polar Biol 23:792-801

Smith REH, Herman AW (1991) Productivity of sea-ice algae: in situ vs incubator methods. J Mar Syst 2:97-110

Smith REH, Clement P, Cota GF, Li WKW (1987) Intracellular photosynthate allocation and control of arctic marine ice algal production. J Phycol 23:124-132

Steeman-Nielsen E (1952) The use of radio-active carbon (C14) for measuring organic production in the sea. J Cons Int Explor Mer 18:117-140

Strickland JDH, Parsons TR (1972) A practical handbook of sea water analysis. Bull Fish Res Board Can 167:1-310

Weissenberger J, Dieckmann, Gradinger R, Spindler M (1992) Sea ice: a cast technique to examine and analyze brine pockets and channel structure. Limnol Oceanogr 37:179-183

Submitted: November 6, 2000; Accepted: February 12, 2001 Proofs received from author(s): October 31, 2001 